\title{
THE INCOMPREHENSION OF TERROR AS A HARBINGER OF "POST-TRUTH”?
}

\author{
Anna Shor-Chudnovskaya \\ Sigmund Freud University, Vienna
}

\begin{abstract}
"I'd like to see M."
"You can't see him," the Komsomol activists explained reluctantly. "He is under arrest."

At that time, arrests were not yet daily routine, not surprising anyone, so I just yelled involuntarily, "For what?" (Kaverin 1989: 98). ${ }^{1}$
\end{abstract}

The epigraph to this article is an excerpt from Epilog [Epilogue], a memoir by the Soviet writer Veniamin Kaverin (1902-1989). For readers living long after the events described, the author considered it necessary to explain why he would ask "For what?" in response to a report of someone's arrest. It is clear from his explanation that that seemingly ordinary and quite logical question was not taken for granted at the time. Kaverin specified that he had asked it only because the repression had not yet reached its peak. This explanation is bewildering: does this mean that he would not have asked such a question later, for example, in 1937? And if not, why?

In reading memoirs of that time, one comes to the conclusion that there was then a special attitude connected with the simple question "For what?" The well-known Soviet philologist and translator Efim Etkind (1918-1999) also considered it necessary to mention this question in his memoirs. In 1948, he accidentally learned that his colleague Tatyana Gnedich (1907-1976) had been arrested in 1944 and was still in detention:

\footnotetext{
${ }^{1}$ Unless otherwise indicated, all translations from Russian are by Martin Malek. Transliterations are given according to the British Standard 2979:1958 system.
} 
I was $[\ldots]$ stunned, $[. .$.$] because we had not known that the poet$ and translator Gnedich had been arrested. For what? In those years no one asked "For what?"; if one used such words, they were preceded by an ironic reservation. "For what?" is an idiot's question (Etkind 2011).

Like Kaverin, Etkind stressed that "For what?" had gradually become inappropriate in talks about arrests and disappearances. And like Kaverin, he does not explain why. Obviously, the political (state) terror and a specific kind of refusal to understand what was happening were closely linked in the experience of those who lived in that era.

Since Mikhail Gorbachev's perestroika policy (1986-1991), a considerable number of archival documents, documentary evidence, and scientific literature dedicated to the years of Joseph Stalin's rule (1923-1953) have been published. However, it seems to me that in many regards one feature has not been given due attention, namely, a specific kind of perception of the Great Terror (which in literature is usually limited to the years 1936$1938)^{2}$ as inaccessible or poorly accessible to logical understanding. Using the example of several authors, in this paper I want to present evidence about the impossibility of understanding political reality under Stalin. My main goal is to consider to what extent the Great Terror contributed to the development of a specific political epistemology, which in my view is part of a certain political culture and which is largely characteristic of later periods of Soviet history, and perhaps even today, because there is still no clear, unambiguous answer to the question "For what?" in Russian society. As sources I will rely especially on texts created by contemporary witnesses during the Great Terror or immediately after Stalin's death. First and foremost, I will consider various works of Russian literature whose authors were the relatives of victims and who tried to capture what was happening to them and to the people around them - how their attitude to the facts, to reality, to the truth changed when it was not possible to explain what was going on with the use of logic. Of course, it is important to always be aware of the fact that these literary creations are only examples

\footnotetext{
${ }^{2}$ Depending on the time frame and the definition of "political persecution" (e.g., how executioners who then went into the death mill themselves should be considered), the number of Gulag victims can vary greatly. Many statistics are difficult or impossible to compare because of the different methods of counting. According to one plausible estimate, between 1930 and 1958 over 20 million people passed through the Gulag and over 2 million died. Many were shot without being sent to labour camps. For data from Memorial, compare Yelena Zhemkova and Arseniy Roginskiîs paper (2016).
} 
- albeit in my opinion particularly meaningful ones - and that other Soviet authors (e.g., Boris Pasternak, Anna Akhmatova, and Yurii Dombrovskii) have also written on these topics. But the examples I have chosen Veniamin Kaverin and Lydia Chukovskaya - are also interesting, precisely because they were among the first Soviet Russian authors to raise these issues and deal with them.

Recently, the term "post-truth" has become the subject of numerous discussions about a new attitude to truth and the new culture of truth that is now particularly visible in Western countries and in Eastern Europe. These disputes can be divided into four main areas:

1. Discussions on the crises of rationality and changes in attitudes towards the truth in the field of philosophy. First of all, this development is occurring under the pressure of various constructivist tendencies and is connected with disputes about the concept of "reality" and the possibilities (and necessity!) of adequately understanding it (Dreyfus \& Taylor 2015; Lyotard 1984; Szaif \& Enders 2006).

2. Discussions on the possibilities of scientific cognition, trust in science and in the objective, "true" results of scientific research and "scientific facts" (Latour 2004; Latour \& Woolgar 1986; Weingart et al. 2017).

3. Discussions about new media (and primarily the internet) and their potential for disseminating incorrect information or, even more importantly, information that cannot be verified and therefore cannot be assessed as correct or incorrect (Pomerantsev 2014; Graves \& Cherubini 2016; Hendricks \& Vestergaard 2019). This includes modern theories about communication processes (Kuznetsov 2011).

4. Finally, discussions on a new attitude towards truth in the political sphere as part of political epistemology and political culture. In this context, "post-truth" means, first of all, denying the possibility or even appropriateness of truth in the public sphere (Arendt 1967; Krastev 2017; Nida-Rümelin 2006). In democratic systems, it seems to mark the transformation of democracy - in which direction, it is difficult to say so far.

It should be mentioned that none of these directions is really new and that all of them characterise the development of thought in the twentieth century. 
This article is devoted to the attitude to truth mentioned in the fourth point, that is, as a part of political culture, and, moreover, in a non-democratic regime. In this context, it would be wrong to think that the term "post-truth" refers only to the manipulative practices of ruling elites. It is equally important to take into account the political consciousness of people who are not endowed with political or state power: the subjects of political thinking and political culture. Their attitude to truth depends on both actual political practices and the political history of society. The attitude to truth in Eastern and East-Central Europe has a specific history that differs from other regions. For East-Central Europe, today's special relations with truth were formed under the influence of political events in the second half of the twentieth century. But in Russia these special relations were no less determined by events that preceded the Second World War.

\section{/// Sofia Petrovna}

I don't know what shook me more in 1937: was it the brutality of the authorities or the degree of human stupidity? (The next winter, I wrote the novella Sofia Petrovna about this stupidity which I hated and which hurt my soul but at the same time aroused pity in me.) (Chukovskaya 2009: 275)

This is how, almost half a century later, in her autobiographical book Procherk [A stroke of the pen], Lydia Chukovskaya (1907-1996) remembered her feelings while writing the novella Sofia Petrovna. What exactly does she mean by "human stupidity"?

Sofia Petrovna is the only contemporary literary evidence of Stalin's terror. ${ }^{3}$ According to the Russian literary critic Dmitry Bykov, this novella is a kind of "live report." Written immediately after the news of her husband's death, the story helped Chukovskaya survive: "I would have hanged myself if I had not willingly or unwittingly fixed on paper what I had experienced. I would have committed suicide as traitors do" (2009: 451). What was the betrayal about? Chukovskaya explained that "[i]t turned out that no less than by Mitya's death [...] I was shocked by my own gullibility to the falsehood of empty words, the ability to deceive myself" (ibid.).

\footnotetext{
3 The poem "Requiem," which Anna Akhmatova wrote between the years 1934 and 1961, is another important testimonial. Chukovskaya's novella is therefore the only literary work that was finished during the time of the Great Terror.
} 
The arrest in 1937 of her husband, the outstanding theoretical physicist Matvei (Mitya) Bronstein, divided Chukovskaya's life into two parts. She saw her husband for the last time a few days before his detention and kept seeking the truth about his fate for the rest of her life. Living in constant anticipation of her own arrest, she wrote Sofia Petrovna in a simple school notebook during the winter of 1939-1940. As the author of such a piece would most likely be shot, she hid it.

Although hating numbers and mathematics all her life, Chukovskaya possessed a rare analytical mind combined with a subtle poetic and artistic flair; she captured the Great Terror as a writer, and, at the same time, as accurately as if she were taking a documentary photo.

Sofia Petrovna is amazing for more than the history of its creation and the fact that the manuscript was miraculously preserved (it was not confiscated by the Soviet People's Commissariat for Internal Affairs, or NKVD, and it did not even disappear during the German siege of Leningrad (19411944) with all its chaos, the devastating famine, and so forth). ${ }^{4}$ The remarkable feature of this testimony about the Great Terror is that it is not about the victims, the inmates of prisons and labour camps who survived or died (about whom Varlam Shalamov, Evgeniya Ginzburg, and Alexander Solzhenitsyn wrote Kolyma Tales, The Steep Route, and The Gulag Archipelago respectively). Sofia Petrovna is dedicated to those who were outside the prison walls and who survived, like Chukovskaya herself - for some reason or by pure luck. But did they remain unharmed? Was it possible not to become a victim (albeit in a specific manner) of the Great Terror by staying at home and therefore out of prison? Chukovskaya gives a negative answer: the "stupidity," the "gullibility to deception," the "ability to deceive," when they suddenly concerned millions of people, were also among the devastating results of the Great Terror.

Both the novella Sofia Petrovna and the autobiographical book A Stroke of the Pen, which Chukovskaya finished a couple of years before the collapse of the Soviet system, are careful, thorough, and at the same time merciless examinations of herself and other characters. The protagonist of the story, Sofia Petrovna Lipatova, is not a lyrical heroine but rather the opposite. In fact, the story is devoted to only one thing: Sofia Petrovna, whose son is arrested, tries to understand what is happening, but is unable to do so. In speaking of the "human stupidity" that struck her while writing the novella, Chukovskaya means incomprehension. Looking back, she felt both

${ }^{4}$ The book was first published in 1965 in Paris in a version that was not authorised by the author. The first publication in the Soviet Union took place only in 1988. 
pity and hatred for Sofia Petrovna. Chukovskaya found herself extremely lonely in her own search for meaning and truth after her husband's arrest. "Not hiding from the truth" was an occupation for a very narrow circle of people, and it was dangerous. But even they were mostly unable to understand: either they were unwilling to dig up the truth or the events were just too incomprehensible at the time.

In $A$ Stroke of the Pen Chukovskaya tells how unbearable it was for her to have conversations with people around her: not with strangers and indifferent people, but with people who sympathised warmly with her, who were concerned about the fate of her husband, and tried to help her. The most intolerable conversations were with other women who had lost their husbands or sons in 1937:

My confrontations with the "incomprehenders" were getting more and more frequent, more and more painful. I couldn't forgive people their incomprehension, although, I repeat, I didn't understand much myself. But the feeling of brotherhood and alliance in the common grief left me almost immediately after I faced the blind, stupefied people. The main source of suffering is my inability to explain and to demonstrate my defencelessness and the lack of proof that I am right (ibid.: 272).

Sofia Petrovna was formed out of this pain, because art, as Chukovskaya believed, is always born out of a desire to understand reality. It is noteworthy that Chukovskaya had not yet established herself as a writer, as she claimed that this novel was her first literary work:

This was the first time I had set pen to paper, because I could do nothing but write. I did not write about Mitya, nor about myself; I wrote about a woman who believes that "we don't imprison people for no reason," but every word was dictated by Mitya's fate $[\ldots]$ and my new condition dictated by my new reality (ibid.: 453).

What was this new reality about? When looking back later, Chukovskaya called 1937 a time of "senselessness." But in Sofia Petrovna she does not seek names for what was happening; the text does not contain the author's reasoning, and there is not a single conclusion, not a single summary explanation. It might be said that the author was trying to be as unbiased as possible. Her task was to provide a very careful description of the 
events, not missing any trivialities. This is how a detailed and honest report from the scene of the accident was born, depriving the author of any hope. Sensitive readers eventually find it hard to breathe, because this story is about total destruction. The relatively short piece shows the destruction of the characters' usual way of life, of personal and professional biographies; the destruction of a family and the relations between people; the destruction of communication, language, words and their meanings; the destruction of comprehension, and, as a consequence, of the human psyche.

Let yourself understand that [they arrest] you "for nothing," "for no reason whatsoever," that murderers kill because it's their profession to kill, and your heart, not even shot by a bullet, will burst into pieces, and you will lose your mind although you have not been shot. Man was hiding from the truth as if from a revolver muzzle pointed at him (ibid.: 268).

Sofia Petrovna is striving for some plausible explanation of what is happening to her son and herself, but she finds herself in a dead end of incomprehension, because the truth is meaningless and therefore unbelievable (nepravdopodobno). And the most believable thing (pracdopodobno) must be a lie, because otherwise it would have to be understood and admitted that society is under the control of murderers. In refusing an extremely absurd-seeming truth, the heroine of the story gradually goes mad. Chukovskaya testifies to what she had repeatedly observed: once in the midst of senseless, gratuitous total violence and total lying, there can be no salvation from despair unless there is faith in the sense of what is occurring in such a world. Such a saving lie for Sofia Petrovna, as well as for millions of other people - Chukovskaya's contemporaries - is the belief that all this cannot "really" be the case - that what is happening is a mistake and a misunderstanding and that, as Soviet common sense postulated, "we don't imprison people for no reason." This crazy belief in an error saves the heroine from suicide.

Chukovskaya repeatedly mentions in her late autobiographical notes that she also partly shared the conviction that "all this" (meaning the events surrounding her) "cannot be real." In 1937, she and her family wondered, "Will the state grab thousands of people in vain? [...] Why? Neither fools nor smart people could answer this question" (ibid.: 278). Another question they asked was "Why, in fact, is it necessary to arrest a person who is obviously innocent and beat him until he confesses that he intended to 
blow up the Smolny? ${ }^{5}[\ldots]$ Where did so many people suddenly come from who could beat the defenceless? [...] And why?" (ibid.: 142-143). It is noteworthy that $A$ Stroke of the Pen, which was written in the early 1980s (and, therefore, decades after the Great Terror) is full of questions to which the author still had no answers.

In her novella, Chukovskaya describes a political situation in which truth is unbelievable, and belief in untruth is the only kind of resistance that Sofia Petrovna can manage. Chukovskaya only gradually found another way for herself: she was able to withstand the despair that her heroine could not bear because she resisted with literature and courageous testimony. She was singular in her readiness to try to understand any - even the most improbable reality - with the help of literature. In remembering Chukovskaya after her death, the literary critic Samuel Lurie said that "she had a literary view of things. [...] And she believed that there, in Russian literature, is the truth" (quoted in Tolstor 2007). It is precisely because Sofia Petrovna does not answer any of the painful questions about why people were arrested and murdered and how this turned out to be possible that the novella documents the possibility of finding the truth. "Do not let the deaths of the innocent grow into renewed executions but into a clear thought. The exact word" - Chukovskaya urged in 1968, believing that it was the writer who was called upon to correct "the murder of the truthful word," which was "one of the blackest atrocities committed for decades" under Stalin (Chukovskaya 1991: 9). But in the 1960s and 1970s Sofia Petrovna was not published in Chukovskaya's homeland, and until the beginning of the perestroika she was constantly persecuted and harassed because she appreciated the truthful word, refused to make concessions to censorship, and wanted to call things by their proper names when speaking about the Great Terror.

\section{/// The Open Book}

In commenting on his novel Otkrytaya kniga [The open book], Veniamin Kaverin admitted once that its plot plays a secondary role. The main issue is the historical context. "I've been waiting for decades for my arrest, especially since the mid-1930s, when the saving formula collapsed: if you're arrested, you are guilty" - Kaverin wrote in his Epilogue ${ }^{6}$ (1989: 129). By

\footnotetext{
${ }^{5}$ Seat of the Leningrad city authorities

${ }^{6}$ Epilogue is one of Kaverin's most frank books, which he decided to write in the 1970s. It was created without any hope for publication. Then the manuscript was secretly sent abroad. It was only thanks to the perestroika that the book, in which Soviet literature is closely intertwined with the history of lack of freedom, was released in the late 1980s in Kaverin's homeland.
} 
the mid-1930s, all logical explanations for the numerous arrests had finally been exhausted for Kaverin. It had become clear that people were arrested for nothing. He escaped this fate, but he constantly worried about his relatives and friends. Like Chukovskaya, Kaverin closely observed the effects of the Great Terror in daily life, and these observations were reflected in his works.

Perhaps the most interesting work in this respect is his novel The Open Book. Like Chukovskaya in her novella, Kaverin wrote his novel not only as a witness but also as a survivor of the events (after more than a decade had passed). Yet Kaverin worked on this long novel for a considerable time. Although he had begun writing already in 1946, he only considered the work finished after Stalin's death, on the eve of Nikita Khrushchev's Thaw, when repression and censorship were relaxed. ${ }^{7}$ However, the work's main difference from Chukovskaya's novella was that Kaverin adapted it to the requirements of censorship. He wrote his novel in such a way that it could be officially published. The Open Book is primarily a fascinating story about the life of scientists and of scientific discoveries in Soviet microbiology and virology in particular. And the atmosphere of "brutal, unresponsive and relentless violence" - as Kaverin described the Great Terror at the end of his life in Epilogue (ibid.: 126) - is only a background to the scientific research and great discoveries. The historical context of the novel is based on the fate of his brother Lev Zil'ber (1894-1966), the founder of Soviet immunology, who was arrested three times under Stalin (in 1930, 1937, and 1940), and on the fate of various other scientists who were killed during Stalin's reign.

Another important difference between Kaverin's novel and Chukovskaya's novella about the ordinary, semi-educated Sofia Petrovna is that the heroes of The Open Book are representatives of the scientific intelligentsia. In fact they are its best representatives, as the prototypes of the main characters were outstanding Soviet scientists. The Open Book is a novel about well-educated people engaged in intense intellectual work. However, Kaverin often portrays their fear and bewilderment, especially when they feel that they understand less of the reality around them than of their labo-

\footnotetext{
7 In 1948, the first part of the novel was published in a journal version, which was significantly changed at the demands of censorship. The publication generated a large number of negative responses, which Kaverin later described as a "coordinated attack" (1989: 297). He repeatedly "adapted" the novel to the requirements of censorship. The first publication of the full version in 1956 also contained numerous concessions to censorship because "the time when it is possible to write about the arrests has not yet come." Later, Kaverin reworked the novel further in order to bring it closer to the original or, as he wrote in 1989, "to the truth" (ibid.: 300). The reflections in this article are based on the version of the novel that was published in 1999. This version is also quoted here.
} 
ratory work. Kaverin would later call their desire to resist the atmosphere of a "consciousness turned inside-out, in which we were all caught at the time" (ibid.: 125) naive: "We learned only after forty years what was actually happening in the country, while at that time our ignorance was a pervasive feature of life" (ibid.: 96). Nevertheless, he finished his novel on an optimistic note.

The main character of the book, Tatyana Vlasenkova, is the only one who continues to ask the stinging question "For what?":

\author{
"By the way, Krushel'skiu has been arrested." \\ This was an old scientist, a member of the Academy of Sciences \\ $[\ldots]$. \\ "Unbelievable! For what?" \\ Rubakin smiled. \\ "Today the weather is nice," he said (Kaverin 1999: 415).
}

In this episode, some patient colleagues try to explain, with evil irony, the meaninglessness of the question. A few years later the husband of the protagonist will be arrested and she will abandon the question, without giving up the desire to understand what is going on. In an attempt to save her husband, she accidentally learns that he was arrested after a denunciation by his colleagues at his research institute. When she looks into the case, she realises that the Great Terror is based on complete lies and that denunciations are only one of its manifestations. Kaverin's heroine concludes that jealousy and whistleblowing are secondary. Instead, it was a special kind of lie, reaching to the highest state level, that made the disappearance of millions of people possible: "Obviously, with all the appearances of scientific logic, black was defined as white and white as black," and all of this turned into a "ruthless act of accusation" (ibid.: 588) that could take the life of any person.

The "dangerously senseless order of things" that reigned in the country (Kaverin 1989: 139) reminded some educated people of the Inquisition of the medieval Catholic Church. Talking about this resemblance in Epilogue and referring to the opinion of his brother, one of the arrestees, Kaverin comes to the conclusion that "there was no resemblance. The actions of the Inquisition did not take place in dumbness, in secret." He concludes that what happened under Stalin did not allow of any comparison (ibid.). He repeatedly called the Great Terror "mute," emphasising that in these years it was not only hard to understand anything, but also impossible to 
use a rational argument, a word, an indication of the facts, a statement - all this made no sense, leaving a person completely defenceless and helpless.

With the help of cautious replicas of his protagonist (it should be recalled that the novel ended after Stalin's death), Kaverin makes it clear that the Great Terror was controlled by a special kind of lie, which slipped away from any meaning. It was a lie that could not be proven to be a lie, because it took the form of absurdity. The deception, having no sense, evaded revelation: "As in Goya's painting, two faces were turned to me - one smiling with a hard-to-believe sincerity, the other - gloomy, with a motionless mouth, with the half-open eyes of a killer" - this is how the protagonist portrays one of the denunciators, and this description surprisingly reflected the common method of having interrogations be conducted by two NKVD investigators - a good one and an evil one - in order to torment the detainees with a schizophrenic bifurcation of interrogation styles as well.

The end of the novel is much more optimistic than the real fate of its prototypes, although Kaverin's brother did in fact manage to survive in a labour camp. Unlike Sofia Petrovna, Kaverin's novel leaves the reader with hope. His main character also firmly believes that "all this" cannot be, but in a quite different way than that of the lunatic Sofia Petrovna. If Sofia Petrovna is no longer able to distinguish lies from truth, Tatyana Vlasenkova retains this ability to the end. If Sofia Petrovna is helpless and insidious, Vlasenkova's behaviour is both braver and more cunning, as she does not give up the hope of being able to expose the denunciators someday. She tries to outwit them. "I spoke quickly, almost without thinking, and taking care only of how to lie more confidently and more precisely. For the first time in my life, I lied with a clear conscience, because it was the only way to defeat another lie against which there was no other weapon" - this is how Kaverin has his protagonist act in the final scene, during a conversation with the main denunciator (1999: 596). While remaining confident that lies and truth could and should be distinguished from each other, Vlasenkova understands that the Great Terror puts her in a situation that, at least, does not yet give her such an opportunity.

Like his main character, Kaverin did not uncompromisingly demand the disclosure of lies. He was brave in repeatedly speaking out against Soviet power and the suffering of the repressions. Yet he also made concessions and censored his works on several occasions. In the final years of his life he bitterly repented having done so: 
I have been deceived without guilt and punished by humiliation and fear. And I believed and did not believe and worked stubbornly, retreating at every step of the way, and got confused in contradictions, proving to myself that the lie is the truth. And I longed to forget the hard dreams in which I had to tolerate meaninglessness and to be cunning and hypocritical (quoted in Starosel'skaya 2017: 172).

\section{/// Faith in the Falsehood versus Pretence in the Truth}

The main characters of these two literary testimonies about life during the Great Terror are examples of opposing political epistemologies and opposing attitudes to political reality. While Chukovskaya's protagonist is finally deprived of the ability to distinguish truth from lies under the influence of the Great Terror and is ready to accept a more plausible lie for the truth, Kaverin's protagonist retains the ability to distinguish truth from lies to the end, but for tactical reasons refuses to do so and resorts to pretence. At the same time, both Chukovskaya and Kaverin confront their characters with a special kind of lie - a lie disguised as something so absurd, outlandish, and nonsensical that it is particularly difficult or even impossible to accept and, thus, to expose.

If we now turn to non-literary sources, such as the historical studies that have appeared in recent years based on archival materials about the NKVD-run detention centres (investigation files, interrogation protocols, intra-departmental correspondence), we will see that these two political epistemologies can be found not only among the non-incarcerated public but also among those arrested by the NKVD, and the variant of Sofia Petrovna seemed to be clearly dominant. As evidenced by the documents available to researchers, the majority of those arrested believed that a mistake had occurred, and they continued to believe it sometimes until their execution or during many years in labour camps. Even they, the direct victims of the Great Terror, who knew much more than those who remained at large, found it difficult to believe the truth and much easier to mistrust it.

It should be remembered that a certain fascination with communist ideas and ideals, even among the victims themselves, led people to have remarkably ambivalent attitudes towards their own individual destinies. Thus, for instance, the well-known Soviet authors Evgenya Ginzburg and Varlam Shalamov remained more or less convinced supporters of the com- 
munist or Soviet model of society even after years in prisons and labour camps, where they had only barely escaped death. This peculiar phenomenon of the deep utopian loyalty of victims and survivors (not to mention their relatives) in regard to a regime which was alone responsible for their humiliation and dehumanisation would have been unthinkable, for example, in the case of the Shoah (compare Schor-Tschudnowskaja 2018). ${ }^{8}$

However, the system of the Great Terror did not provide much opportunity for proving one's innocence, although there were some rare cases. The Terror had other aims: the essence of the interrogations and the whole "investigation" was to demand that the arrested person confess (to "crimes" she or he had not committed). This was neither an investigation nor a verification or comparison of facts but pressure on already convicted persons to confess their guilt. Perhaps this is why there is an impression that the Great Terror held on to a special kind of lies, which resembled absurdity and nonsense, that is, they contained not so much the opposite of the truth as a lack of meaning as such. This sense of meaninglessness has been documented in numerous testimonies. For example, Petr Vasil'evich Karamyshev, the former head of the NKVD administration for the Nikolaev region (today's Ukraine), who was acquitted and released after his first arrest and executed after the second, wrote about his time in prison:

This is more than I can bear, because I have already experienced such a great deal of the suffering which a man who believes in the triumph of the Bolshevik truth can endure. I ask you therefore to intervene in this matter, to put an end to all these cruel and senseless persecutions (quoted in Savin et al. 2018: 7).

The historian Igal Khalfin, who analysed the interrogation protocols from the second half of the 1930s, came to the conclusion that almost all these documents contain fictitious crimes. What is remarkable about them is not only that they have nothing to do with the real thoughts and deeds of the arrested person, but also that they often contradict the laws of logic and even the laws of nature. Through sophisticated torture, which was allowed and widely used at that time, the arrested persons were forced to confess that they had committed senseless acts. With bitter irony, Khalfin called this the "collective creativity of the Chekists" (2019). We might also speak

${ }^{8}$ See also Yuri Slezkine (2017), who treats Bolshevism as a kind of sectarianism, emphasising the meaning of faith ("apocalyptic millenarism") for this ideology. 
of a collective psychosis, but Khalfin rigorously dismissed any psychiatric terms. Being interested primarily in the extent to which the Great Terror was understood by those who performed it, he stated that

[f]or researching the NKVD's methods of investigation, terms such as "irrationality," "paranoia," or "violence bacchanalia," which are so common in the literature on this period, do not explain much. There is no need to refer to psychosis and other psychiatric hallmarks to understand how the Stalinists understood guilt. The process of investigation, starting with the arrest, proceeding through interrogations, and ending with a verdict and a gunshot, was meaningful and understandable to the investigators, and even for the executioners, who had to shoot dozens of people per shift (Khalfin 2019; emphasis added).

Khalfin insisted that the "senselessness" of the Great Terror contained its own meaning, and the "lack of logic" - its own logic. And if the victims of the Great Terror mostly did not understand at all what was going on, it was more or less clear to its executors. Khalfin believed that the meaning of the "senselessness of 1937" (Chukovskaya) has to be sought on the side of the perpetrators of the terror. And this meaning, as Khalfin concluded after a detailed study of documents about the Great Terror, turns out to be irrational. He considers that the behaviour of NKVD investigators was guided by a logic similar to some kind of "demonology," that is, a search for the forces of evil from Beyond. "Demonology' is not mentioned directly, but it works. Without it, it is impossible to kill so many people," said Khalfin in one of his presentations (quoted in Litvinova 2015). And, as other historians have done before, he compares the Stalinist repressions to the Inquisition and the search for heretics, although he recognises that this comparison is problematic. However, he sees an undeniable similarity in one thing: Stalin's society was characterised by an eschatological, or, more precisely, "millenarist understanding of time" (Khalfin 2019).

I analyse the Bolshevik understanding of time. This was changing. However, for the Bolsheviks it was very important to know their place in history. After 1936, the Bolsheviks believed that the end of time had come and that it was necessary to sum up the final results. And if a person was "wrong," he should be physically destroyed. This was the logic (quoted in Litvinova 2015). 
For Khalfin, the semantic foundation of the Great Terror was the specific understanding of guilt, the search for "demons" and the conviction that any one could turn out to be one. And according to Khalfin, as this confidence began to dominate, the language, the main epistemological tool, was devalued and replaced by a suggestive gesture: "You are guilty." And this in turn was documented by thousands of self-incriminations and confessions beaten out under torture: "Yes, I am guilty."

Soviet society, as seen by the political (Soviet) elite and the NKVD, was declared guilty of "demonism" in advance. Thus, the political regime, which set itself the goal of separating its "own" (in Russian svoi) people, who have the ("holy") truth on their side, from its "enemies," made this very distinction impossible because it provided no precise criterion for determining "its own." According to Khalfin, it turns out that if it is impossible to separate one's "own" from one's "enemies" then the necessary consequence of such an "end of time" is the impossibility of separating the truth from lies. No matter what the arrested person says, in the eyes of the investigator it is most likely a lie. Thus, it is impossible for the person to prove his or her innocence in relation to the charges, however absurd they may be.

If a political epistemology in such a society is possible at all, it is thus an epistemology of spoofing (podmena), in which truth is considered to be a lie and lies are true, and in which it is impossible to label lies as such because they take the form of absurdity. Survival in such a society was possible only by chance, when one could save oneself by a blind belief in the plausibility of lies (like Sofia Petrovna) or by slyness (like Tatyana Vlasenkova). And if the years of Stalin's terror (of which there were no less than twenty in total) rooted such a political epistemology in the society, then the following decades may have relativised it, but not abolished it.

\section{/// Historical Heritage and Political Epistemology}

Political epistemologies are subject to constant change, and if they are even partially conserved it indicates that they retain their adaptive function, or, in other words, the political reality keeps individual patterns unchanged. Numerous researchers have documented a certain political consistency to the decades of the Soviet regime after Stalin's death (1953) and an undoubted continuity with the years of Stalin's rule: a peculiar mixture of dream, illusion, utopia, deception, and lies formed the political foundation of Soviet society until its end. The veiling of political realities (Dietrich Beyrau), and 
the classic formula of the "cunning man" (according to Soviet and Russian sociologist Yuri Levada) who knew that the main thing was not reality but how it was mediated, were dominant features of politics in the USSR until its very end (Schor-Tschudnowskaja 2019).

In considering the post-Soviet period of development up to the present time, it is possible to point to various aspects that testify to a certain stability of the political epistemology assimilated from Soviet times. Over the last two decades (after 1999), we have seen an increase in confidence that it is impossible for a political subject to separate truth from lying and that the sphere of public administration and political interests is, by definition, a place where deception prevails. Both from my own observations and those of other commentators it would seem that there has been a "normalisation of lying" in Russian politics in this time (Skillen 2019). The opposition politician Grigorii Yavlinskir noted back in 2011 that

[t]he main political problem of our country is not the level and quality of democracy or the protection of freedoms and rights of citizens, as it is commonly believed, but an unlimited and total lie as the basis of the state and public policy (Yavlinski1 2011).

The well-known political scientist Vladimir Pastukhov, for his part, commented on political processes in Russia as follows:

If the goal of poetry is nothing but poetry, the goal of terror is terror. It has no other "practical" goals. This is a ritual that will now be performed daily by a new Russian religious sect - the "order of law enforcers." Like any ritual, it has long been - and is unrelated to reality, it has no clear practical meaning, it has only a sacral meaning, and it is self-sufficient. This is why there is no "For what?" and "Why?" here (Pastukhov 2019).

If one did not know the date of this comment and the political events it describes, one might think that these words refer to the distant Soviet past. The term "religious sect," the lack of connection with reality, and the eternal question "Why?" which remains without a meaningful answer, have all been addressed above in this article. But Pastukhov was commenting on current events: in particular, the various persecutions of opposition candidates in the run-up to elections to the Moscow City Parliament in September 2019 and the numerous detentions at public rallies against these 
persecutions (as well as the administrative and judicial harassment of detainees, primarily in Moscow). Being well aware of Russia's history in the twentieth century, Pastukhov consciously turned to terminology borrowed from historical sources to highlight the parallels between the present day and the Soviet past.

For its part, the Human Rights Centre of the Russian NGO Memorial points out that numerous legal charges have been fabricated for the sake of such persecutions. ${ }^{9}$ In modern Russian judicial practice it is very difficult to rationalise and substantiate the evidence by a consideration of facts. ${ }^{10}$ In addition, there are numerous cases of bullying during the investigations (Davidis 2018), although no one has exact figures in regard to their extent. And so the Memorial staff finds it necessary and justified to draw some parallels between current and past political practices.

In summary, in regard to the continuing influence of the political epistemology established during the years of Stalin's terror, it is worth noting that despite all the apparent differences between the systems of that time and today's Russia, one important similarity is striking: the dominant feature of the political culture in Russia is (and remains) a high level of conviction that the ruling political class is deceiving the population and that lies are an inseparable attribute of politics and public administration. As a consequence, the levels of slyness and sham, as adaptive strategies of the population, remain extremely high. The well-known Russian sociologist Lev Gudkov (2019), in commenting on the results of a recent poll, pointed out that the semantic dominant perception of power today is "criminal, corrupt" (ca. $46 \%$ of respondents), that is, deceptive, and that this perception has obviously Soviet origins.

The final example is an extensive recent study by the Russian sociologist Irina Olimpieva (2019), who investigated how young people perceive corruption (as a form of deception incorporated into state structures and political power). She found that young people consider corruption to be the main component of state power, as well as of business, which is largely controlled by the state. At the same time, the respondents revealed their feelings of complete helplessness in the current situation and their confidence that it could not be changed: "Young people do not believe in the possibility of a fundamental change in the state of corruption in Russia in

\footnotetext{
9 See, for example, Otkrytaya Politsiya (2016).

${ }^{10}$ Some observers have raised the question of whether there is even a presumption of innocence in Russia today, especially in politically motivated trials. It would actually seem that the defendant has to prove that he or she is not guilty - and this cannot be done because the facts and evidence are not taken into account by the court. I thank Jan Surman for this hint.
} 
the foreseeable future. It is believed that the state must fight corruption, but the state itself is corrupt" (Olimpieva 2019: 6).

In the context of such a situation, it is legitimate to ask to what extent "post-truth" is a new phenomenon for Russia, if we consider its political aspect alone. It may be concluded that the opportunities offered by the new media, and especially the internet, to manipulate information in such a way that it is practically impossible to distinguish between true and false information have been gratefully received by Russian society and the political elite precisely because the propensity for not distinguishing between truth and lies came to be rooted in the political epistemology of Russian society long before the new technical and media opportunities appeared.

Of course, the political epistemology of the Russian population today has many new traits in comparison with Soviet times. Among these traits, one important circumstance allows us to speak of a widespread new attitude to truth in Russia - and it is not the development of virtual technologies. I mean the fact that - as can be seen in numerous public discussions - in the perception of many Russians the West today appears to be a political community that is rapidly losing its democratic foundations and therefore, in terms of "the culture of truth," is increasingly approaching Russian society. The prefix "post" in relation to the political "culture of truth" in today's society in Russia conveys the great extent to which the balance of power in the global context has shifted in the people's perception in comparison to the Soviet period. Today, the majority of citizens in Russia feel that there is "no truth" - not only in the domestic politics of their country, but also abroad. There is less and less hope of distinguishing lies from the truth, because the image of an alternative attitude to the truth, which strictly enforced the boundary between truth and lies, and the possibility of exposing lies, has practically vanished. It was this idealised attitude to truth (and to lies) that was ascribed to Western societies in Soviet times and served as a model and a benchmark, albeit one that was then not (yet) attainable. The consequences of the loss of this standard for Russian society have yet to be examined.

Translated by Martin Malek 
Bibliography:

/// Arendt H. 1967. “Truth and Politics," https://idanlandau.files.wordpress.com/2014/12/arendt-truth-and-politics.pdf, accessed 4.05.2020. [Originally published in The New Yorker on 25 February 1967].

/// Bykov D. 2016. Lidiya Chukouskaya "Sofya Petrovna". 1939 god [Lydia Chukovskaya's "Sofia Petrovna”: The year 1939], Chukfamily, http://www. chukfamily.ru/lidia/biblio/articles-biblio/dmitrij-bykov-lidiya-chukovskaya-sofya-petrovna-1939-god, accessed 4.04.2020.

/// Chukovskaya L. 1991. "Ne kazn', no mysl', no slovo. Otkrytoe pis'o v gazetu 'Izvestiya' k 15-letiyu so dnya smerti Stalina" [No execution, but thought and words: Open letter to the newspaper "Izvestia" on the 15th anniversary of Stalin's death], [in:] L. Chukovskaya, Sverstniku [To a peer], Ogonëk, pp. 7-12.

/// Chukovskaya L. 2009. Procherk [A stroke of the pen], Vremya.

/// Davidis S. 2018. Rossiǔskie politraklyuchennyev 2018 godu: situatsiya i tendentsii [Russian political prisoners in 2018: Situation and trends], Memorial, https://memohrc.org/sites/all/themes/memo/templates/pdf.php?pdf=/ sites/default/files/rossiyskie_politzaklyuchennye_-_izmeneniya_i_ tendencii_v_sentyabre_2018.pdf, accessed 4.04.2020.

/// Dreyfus H., Taylor C. 2015. Retrieving Realism, Harvard University Press. /// Etkind E. 2011. "Dobrovol'ny1̆ krest" [Voluntary cross], Novaya gazeta, vol. 93, https://www.novayagazeta.ru/articles/2011/08/24/45598-dobrovolnyy-krest, accessed 4.04.2020.

/// Graves L., Cherubini F. 2016. The Rise of Fact-Checking Sites in Europe, Reuters Institute for the Study of Journalism, University of Oxford.

/// Gudkov L. 2019. "Obrazy vlasti, sovetskoŭ i nyneshneî” [Images of power, Soviet and current], Levada-Tsentr, 5.08.2019, https://www.levada. ru/2019/08/05/obrazy-vlasti-sovetskoj-i-nyneshnej/, accessed 4.04.2020.

/// Hellbek Y. 2017. Revolyutsiya ot pervogo litsa: dnevniki stalinskou épokbi [Revolution on my mind: Writing a diary under Stalin], Novoe literaturnoe obozrenie.

/// Hendricks V.F., Vestergaard M. 2019. Reality Lost: Markets of Attention, Misinformation and Manipulation, Springer. 
/// Kaverin V. 1989. Epilog [Epilogue], Moskovskiy rabochiy.

/// Kaverin V. 1999. Ocherk raboty. Otkrytayakniga. Literaturnye zametki. Izbrannye pis'ma [A sketch of the work. An open book. Literary notes. Selected letters], Gud'yal-Press.

/// Khalfin I. 2019. Germenevtika NKVD [Hermeneutics of the NKVD], unpublished draft manuscript, Centre for Independent Social Research, https://cisr.pro/news/vystuplenie-igala-halfina-s-obsuzhdeniem-temy-dopros-v-nkvd/, accessed 16.09.2020.

/// Krastev I. 2017. "The Rise of the Paranoid Citizen," The New York Times, 16.03.2017, https://www.nytimes.com/2017/03/16/opinion/the-rise-ofthe-paranoid-citizen.html?curator=MediaREDEF, accessed 4.05.2020.

/// Kuznetsov M.M. 2011. Opyt kommunikatsii v informatsionnuyu épokhu. Issledovatel'skie strategii T.V. Adorno i M. Maklyuéna [The experience of communication in the information age: Research strategies of T.W. Adorno and M. McLuhan], Russian Academy of Sciences, Institute of Philosophy. [Available at https://iphras.ru/uplfile/root/biblio/2011/kuznetsov.pdf, accessed 4.04.2020].

/// Latour B. 2004. "Why Has Critique Run Out of Steam? From Matters of Fact to Matters of Concern," Critical Inquiry - Special Issue on the Future of Critique, vol. 30(2), pp. 225-248.

/// Latour B., Woolgar S. 1986. Laboratory Life: The Construction of Scientific Facts, Princeton University Press.

/// Litvinova E. 2015. “Ot Savla к Pavlu” [From Saul to Paul], Cogita!ru, 18.05.2015, http://www.cogita.ru/analitka/otkrytye-diskussi/ot-savla-kpavlu, accessed 4.04.2020.

/// Lyotard J.-F. 1984. The Postmodern Condition: A Report on Knowledge, University of Minnesota Press.

/// Nida-Rümelin J. 2006. Demokratie und Wabrheit, Verlag C.H. Beck.

/// Olimpieva I. 2019. Rossiǔskaya molodëz̧̧’ $i$ korruptsiya [Russian youth and corruption], Centre for Independent Social Research, https:/cisr.pro/publications/russian-youth-and-corruption-study-report-in-russian/, accessed 4.04.2020.

/// Otkrytaya Politsiya. 2016. "Interv'yu s Olegom Petrovichem Orlovym, chlenom Soveta pravozashchitnogo Tsentra 'Memorial”" [Interview with 
Oleg Petrovich Orlov, member of the Council of the Human Rights Centre "Memorial"], https://openpolice.ru/pages/zhiznennye-situacii/memohrc/, accessed 6.06.2020.

/// Pastukhov V. 2019. “Triumf sily. Moskva c stilistike Rifenshtal"” [A triumph of power: Moscow in the Riefenstahl style], Radio Ekho Moskvy, 5.08.2019, https://echo.msk.ru/blog/pastuhov_v/2477023-echo/, accessed 4.04.2020.

/// Pomerantsev P. 2014. Nothing Is True and Everything Is Possible: The Surreal Heart of the New Russia, PublicAffairs.

/// Savin A., Teplyakov A., Yunge M. 2018. "Vvedenie" [Introduction], [in:] "Ékho bol'shogo terrora", V. 3, Chekisty Stalina v tiskakh "sotsialisticheskou zakonnosti". Égo-dokumenty 1938-1941 gg. ["The echo of the Great Terror," vol. 3, Stalin's Chekists in the grip of "socialist legality," testimonials 19381941], Probel-2000, pp. 7-26.

/// Schor-Tschudnowskaja A. 2018. "Die Attraktivität der sowjetischen Vergangenheit und Neubeginn: Zeitperspektiven im postutopischen Russland," Psychosozial, vol. 4(154), pp. 125-137.

/// Schor-Tschudnowskaja A. 2019. "Das schwierige Erbe von Utopie, Illusion und Betrug," [in:] "So ist er ein Weder-Noch, ein Sowobl-als-Auch...": Beiträge zur Literatur und Kultur, eds. J. Flinik, S. Gromadzki, M. Stolarzewicz, A. Wolkowicz, W. Zahaczewski, Peter Lang, pp. 205-219.

/// Skillen D. 2019. "Post-Truth and Normalised Lies in Russia," [in:] Public Service Broadcasting and Media Systems in Troubled European Democracies, eds. E. Połońska, C. Beckett, Palgrave Macmillan, pp. 359-382.

/// Slezkine Y. 2017. The House of Government: A Saga of the Russian Revolution, Oxford University Press.

/// Starosel'skaya N.H. 2017. Kaverin, Molodaya gvardiya.

/// Szaif J., Enders M., eds. 2006. Die Geschichte des philosophischen Begriffs der Wahrheit, De Gruyter.

/// Tolstoŭ I. 2007. "Lidiya Korneevna Chukovskaya - vchera i segodnya" [Lydia Korneevna Chukovskaya - yesterday and today], Radio Svoboda, 11.03.2007, https://www.svoboda.org/a/382426.html, accessed 4.04.2020.

/// Weingart P., Wormer H., Wenninger A., Hüttl R.F. 2017. Perspektiven der Wissenschaftskommunikation im digitalin Zeitalter, Velbrück Wissenschaft. 
/// Yavlinskiŭ G. 2011. "Lozh' i legitimnost"” [The lie and the legitimacy], Radio Svoboda, 6.04.2011, https://www.svoboda.org/a/3547924.html, accessed 16.09.2020.

/// Zhemkova E., Roginskiu A. 2016, Mę̧hdu sochuvstviem i ravnodushiem - reabilitatsiya zhertv sovetskikh repressiu [Between compassion and indifference - the rehabilitation of the victims of Soviet repressions], Memorial, https://www.memo.ru/media/uploads/2017/08/22/mezhdu-sochuvstviem-i-ravnodushuem_reabilitacia-zhertv-sovetskikh-repressiy.pdf, accessed 4.04.2020.

\section{/// Abstract}

This article is devoted to the attitude to truth as a part of political epistemology and of political culture in post-Soviet Russia. It considers the extent to which the Great Terror contributed to the development of a specific political epistemology, which is also largely characteristic of later periods of Soviet history and perhaps even of today. Of particular interest is the population's perception of the terror as inaccessible or poorly accessible to logical understanding. As main sources, the article relies on two literary texts: Lydia Chukovskaya's Sofia Petrovna and Veniamin Kaverin's The Open Book. Despite all the apparent differences between the Soviet system and today's Russia, one important similarity is striking: over the last two decades (after 1999) there has been a visible increase in the belief that it is impossible for a political subject to separate truth from lying and that the sphere of public administration and political interests is, by definition, a place where deception prevails. This article discusses the potential historical roots of this certainty.

Keywords:

post-truth, Russian political culture, Soviet and Russian literature, Soviet history, Stalinist purges

/// Anna Shor-Chudnovskaya - assistant professor at the Faculty of Psychology at Sigmund Freud University in Vienna, Austria. She is a sociologist and psychologist with the following fields of interest: the history of Soviet society, Russian culture and literature, everyday life in the Soviet Union, the post-Soviet transformation of Russian society, the formation of current sociological theory, etc. Her research is focused on social patterns 
of interpretation in Soviet and post-Soviet Russian societies. She is the author of numerous works which have been published in several countries, including: "Sila i slabost' obshchestvennoj kriticheskoi refleksii v gody perestrojki" [Strengths and weaknesses of social critical reflection in the perestroika years] in Poslednee desyatiletie sotsializma. Transformatsionnye protsessy $v$ GDR i v Sovetskom Soyuze [The last decade of socialism: Transformation processes in the GDR and the Soviet Union], ed. O. Nagornaya (Novyj Hronograf, 2016); "Young Russians about Their Family's Soviet Past: A Nostalgic, Post-Utopian or Retrotopian Approach?” in the journal Mir Rossii (2018); "Das schwierige Erbe von Utopie, Illusion und Betrug in der postsowjetischen russländischen Gesellschaft" in "So ist er ein Weder-Noch, ein Sowobl-als-Auch...”: Beiträge zur Literatur und Kultur, ed. J. Flinik et al. (Peter Lang, 2019).

ORCID: https://orcid.org/0000-0003-3999-2070

E-mail: anna.schor-tschudnowskaja@sfu.ac.at 